\title{
ALAT PENUNTUN TUNANETRA BAGI PENYANDANG TUNANETRA LINGKUP UNJ BERBASIS ARDUINO DAN KOMPAS
}

${ }^{1}$ Ade Riza Priambodo, ${ }^{2}$ Muhammad Rif'an, ${ }^{3}$ Nur Hanifah Yuninda

${ }^{1,2,3}$ PendidikanTeknik Elektro, Fakultas Teknik, Universitas Negeri Jakarta

\begin{abstract}
Man was created perfect but in its development are not all born normal. Humans are born so called in need special, special man in need of them is deaf, blind and tunawicara. Required tools that can significantly impact that is guiding the blind tools can serve as a guiding visually impaired in performing daily activities

Research methods used in this study i.e. method using RnD. This research was conducted at the University of Jakarta Country in April 2018, testing is done i.e. test modules, test compass GPS module, test module DF Player, and Test the motor gear box DC

Based on the results of the research there is a compass that the module obtained different results due to the large number of different metals around testing, testing the GPS module obtained as a result of appropriate coordinates realtime guiding tool for visually impaired the test runs, the Player can function DF module fits well, testing module gear box can function in accordance with the specified distance.
\end{abstract}

Keywords : Blind, Compass, Arduino

\begin{abstract}
Abstrak
Manusia diciptakan sempurna namun dalam perkembangannya tidak semua terlahir normal. Manusia yang lahir demikian disebut dengan berkebutuhan khusus, manusia berkebutuhan khusus diantaranya adalah tunarungu, tunawicara dan tunanetra. Maka dibutuhkan alat yang dapat berdampak signifikan yaitu alat penuntun tunanetra dapat berfungsi sebagai penuntun tunanetra dalam melakukan aktifitas sehari hari.

Metode penelitian yang digunakan dalam penelitian ini yaitu menggunakan metode RnD. Penelitian ini dilakukan di Universitas Negri Jakarta pada bulan April 2018, Pengujian yang dilakukan yaitu menguji modul kompas, menguji modul GPS, menguji modul DF Player, dan Menguji motor gear box DC

Berdasarkan hasil yang penelitian yang didapatkan bahwa modul kompas terdapat hasil yang berbeda beda dikarenakan banyaknya unsur logam disekitaran pengujian, pengujian modul GPS didapatkan hasil kordinat sesuai realtime selama alat penuntun tunanetra berjalan, pengujian modul DF Player dapat berfungsi sesuai dengan baik, pengujian modul gear box dapat berfungsi sesuai dengan jarak yang ditentukan.
\end{abstract}

Kata Kunci : Tunanentra, Kompas, Arduino

\section{PENDAHULUAN}

Manusia diciptakan sempurna namun dalam perkembangannya tidak semua terlahir normal. Manusia yang lahir demikian disebut dengan berkebutuhan khusus, manusia berkebutuhan khusus diantaranya adalah tunarungu, tunawicara dan tunanetra.

Tunanetra adalah tidak berfungsinya indra penglihatan yaitu mata. Mata sebagai indra penglihatan dalam tubuh manusia menduduki peringkat utama (analisa,2014;6), sebab membantu manusia untuk beraktivitas, di samping indra sensoris lainnya seperti pendengaran, perabaan, penciuman, dan perasa. Begitu besar peran mata sebagai salah satu indra yang sangat penting, maka dengan terganggunya indra penglihatan seseorang berarti akan kehilangan fungsi kemampuan visualnya untuk merekam objek dan peristiwa fisik yang ada di lingkungannya, berdasarkan tingkat gangguannya tunanetra dibagi menjadi dua, yaitu buta total (total blind), dan yang masih mempunya sisa penglihatan (low vision) (Pradopo, 1977)

Universitas Negeri Jakarta adalah salah satu pilihan para calon mahasiswa disabilitas untuk melanjutkan jenjang pendidikan tinggi, di Universitas Negeri Jakarta khususnya di Fakultas Pendidikan Luar Biasa banyak terdapat mahasiswa disabilitas yang terdaftar pada tahun angkatan 2009 - 2017 berjumlah 15 mahasiswa, dan mahasiswa aktif pada Tahun 2017 berjumlah 7 mahasiswa dan diantara mahasiswa tunanetra berjumlah 3 orang, namun fasilitas bagi penyandang disabilitas khususnya tunanetra sangat tidak memadai diantaranya tidak adanya trotoar khusus atau sering disebut trotoar pemandu, sehingga para mahasiswa tunanetra pada Universitas Negeri Jakarta menglami kesulitan untuk berjalan pada jalur yang tepat dan aman walaupun tunanetra sudah mengunakan tongkat dalam kehidupan sehari hari.

Tongkat adalah salah satu unsur penting dalam kehidupan penyandang disabilitas 
khususnya tunanetra, dan tongkat adalah sebuah alat yang dapat digunakan tunanetra untuk mengetahui kondisi lingkungan yang dia lalui. Dengan mengetahui suatu lingkungan dengan mengunakan tongkatnya tunanetra dapat berjalan dengan lebih aman. Sayangnya tongkat yang sudah ada saat ini masih sangat manual fungsinya, dikarenakan para penyandang tunanetra kesulitan untuk mengetahui dimana berada, halangan apa yang ada berada di depannya dikarenakan kurangnya fasilitas penyandang disabibilitas khususnya tunanetra pada Universitas Negeri Jakarta.

Beberapa kajian telah dilakukan untuk mengaplikasikan alat bantu navigasi bagi penyandang tunanetra sebagai alat yang dapat memberikan informasi kepada pemakai yang dapat diterjemahkan secara mudah. Penelitian ini dilakukan dengan referensi dari beberapa jurnal yang mengangkat topik penelitian alat bantu navigasi bagi penyandang tunanetra ini penelitian-penelitian yang sudah dilakukan terlebih dahulu Alat Bantu Navigasi Penyandang Tuna Netra Menggunakan Sensor Ping dan Buzzer Wakhyu Dwiono, Siska Novita Posma Teknik Telekomunikasi Politeknik Caltex Riau, Cara kerja alat Pada alat bantu navigasi ini, cara kerja mengunakan Tag RFID yang diletakan di tempat tempat tertentu guna memberikan informasi berupa nama tempat berupa suara Pengembangan Sarung Tangan Sonar Sebagai Alternatif Alat Bantu Navigasi Bagi Tunanetra Menggunakan Arduino, pada penilitan selanyutnya oleh Yudhi Triarnowo, Fakultas Teknik Elektro Universitas Telkom, april 2013, cara kerja alat pada alat bantu ini mengunakan sarung tangan yang memanfatkan sensor ultrasonic yang memberikan informasi halangan dan sebagai peringatan motor vibrator menghasilkan getaran

Berdasarkan latar belakang yang telah diuraikan, maka dibuatlah alat bantu navigasi tunanetra yang lebih spesifik. pada alat bantu navigasi ini, digunakan sistem mikrokontroler Arduino, Kompas, GPS, dan speaker sebagai media informasi untuk tunanetra sehingga diharapkan dapat diwujudkan alat bantu navigasi bagi penyandang tunanetra yang efektif serta mudah dioperasikan

\section{METODE PENELITIAN}

Pada tahap awal penelitian yaitu melakukan studi literatur, pada tahap ini dicari referensireferensi berupa buku, artikel, serta jurnal-jurnal yang terkait dengan pengetahuan-pengetahuan dasar tentang alat penuntun tunanetra.

Cara kerja alat penuntun tunanetra guna membantu tunanetra ini dimulai dengan menentukan desain alat yang akan dibuat, pada dasarnya alat ini terbagi menjadi tiga bagian yang terhubung dengan kabel. Bagian pertama merupakan bagian inti pemrosesan dimana arduino dan daya dari baterai ditempatkan, bagian kedua adalah bagian sensor, dan bagian ketiga adalah GPS.

Bagian inti ini akan diletakan pada akrilik yang di pasangkan roda serta tongkat yang memudahkan tunanetra menuju tempat yang di tuju dengan selamat.

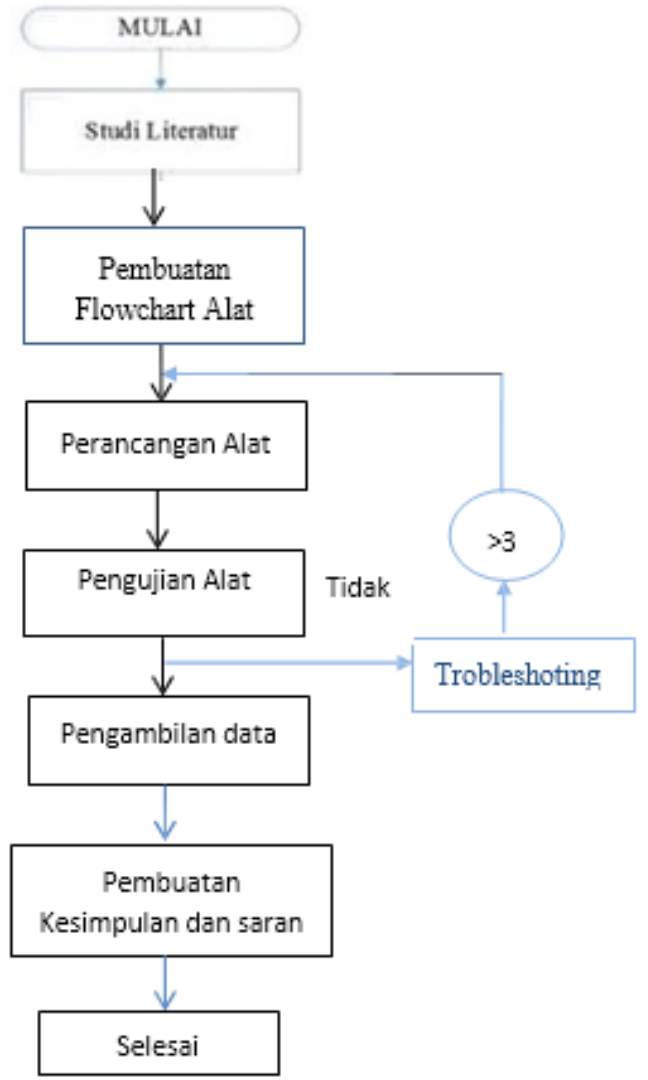

Gambar 1. Skema Penelitian

\section{HASIL DAN PEMBAHASAN}

Untuk mengukur kinerja dari alat yang telah dibuat, maka dilakukan pengujian pada alat. Pengujian dilaksanakan di Universitas Negri Jakarta, yang berlokasi berada Jakarta Timur, uji coba dilakukan 2 Hari, Pengujian dilakukan per blok system dan keselurahan sistem. 


\section{Hasil Modul Kompas CMPS10}

Kompas CMPS10. Pengujian bertujuan untuk mengetahui akurasi pembacaan arah mata angin yang dibaca dalam bentuk nilai sudut $0^{\circ}-$ $359^{\circ}$ oleh modul kompas CMPS10.

Sistem minimal yang dibutuhkan dalam pengujian ini adalah modul kompas CMPS10, mikrokontroler Arduino uno, dan modul LCD karakter. Pada pengujian ini digunakan kompas digital pada android sebagai pemberi acuan arah $0^{\circ}$. Data hasil pengujian modul kompas CMPS10 ditunjukkan dalam Tabel 1.

Tabel 1 Hasil Uji Coba Modul Compas

\begin{tabular}{ccccc}
\hline NO & Arah & $\begin{array}{c}\text { Modul } \\
\text { Compas }\end{array}$ & $\begin{array}{c}\text { Compas } \\
\text { Digital } \\
\text { Android }\end{array}$ & Error \\
\hline 1 & Utara & $354 \circ$ & $351^{\circ}$ & $1 \%$ \\
2 & Timur & $91 \circ$ & $90^{\circ}$ & $1 \%$ \\
3 & Selatan & $184 \circ$ & $184 \circ$ & $1 \%$ \\
4 & Barat & $268^{\circ}$ & $262^{\circ}$ & $3 \%$ \\
& & Rata - rata & $2,75 \%$ \\
\hline
\end{tabular}

Berdasarkan data yang diperoleh peneliti, modul kompas yang di bandingkan dengan kompas digital pada android diproleh hasil seperti pada tabel 1. Terlihat perbedaan hasil yang di peroleh dari modul kompas dengan kompas digital ini di karenakan beberapa faktor antara lain : pada saat pengujian alat terdapat unsur logam di sekitar yang membuat modul kompas dengan kompas pada android memiliki hasil yang berbeda beda.

\section{Hasil Modul GPS}

Uji coba alat tracking pada bagian alat tunanetra yang dipasang modul GPS untuk mengambil data kordinat setiap posisi alat tunanetra yang di lewati, dengan 26hotodiod keberhasilan uji coba alat tracking untuk tunanetra adalah modul GPS dapat menerima data posisi dari satelit dan arduino dapat mengolah data posisi yang didapat dari modul GPS dan mengirimnya ke database (Memory card) yang berisi kordinat latitude dan longitude.

Tabel 2 Hasil Uji Coba Modul GPS

\begin{tabular}{clcc}
\hline NO & \multicolumn{1}{c}{ Lokasi } & \multicolumn{2}{c}{ Kordinat } \\
& & Longitude & Latitude \\
\hline 1 & Perpustakaan UNJ & 106.878253 & -6.194135 \\
2 & Pertigaan & 106.878344 & -6.193714 \\
& Perpustakaan UNJ & & \\
3 & Pertigaan FSI & 106.878526 & -6.193708 \\
& Albiruni & 106.878467 & -6.193490 \\
4 & Gedung Teknik & 100 & \\
\hline
\end{tabular}

Berdasarkan hasil pengujian modul GPS sesuai pada tabel 2 ini bertujuan mengetahui kinerja modul GPS dapat sesuai mengirimkan data kordinat atau tidaknya sesuai jalur yang telah di lewati alat penuntun tunanetra, hasil dari modul GPS ini dapat di lihat dari database MMC yang mencatat kordinat latitude dan longitude secara realtime selama alat penuntun tunanetra ini berjalan.

\section{Hasil Modul DF Player}

Pengujian bertujuan untuk mengetahui apakah suara yang diputar oleh modul DF Player sesuai dengan perintah yang dikirimkan melalui komunikasi serial oleh mikrokontroler. Sistem minimal yang dibutuhkan dalam pengujian ini adalah SD card, modul DF Player, Arduino Untuk memainkan suara mikrokontroler mengirimkan data serial ke DF player dan speaker sebagai output.

\begin{tabular}{ccc} 
& Tabel 3 Hasil Uji Coba Modul DF Player \\
\hline No & Perintah serial & Suara \\
& Microcontroler & \\
\hline 1 & LR (Lurus) & Berfungsi \\
2 & KR (Kiri) & Berfungsi \\
3 & KN (Kanan) & Berfungsi \\
4 & Stop & Berfungsi \\
\hline
\end{tabular}

Pengujian ini bertujuan mengetahui kinerja modul DF player pada tabel 3. Pada alat ini modul DF player dapat bekerja dengan baik, dengan di ketahui dari speaker yang aktif memberikan informasi sesuai dengan perintah yang di berikan oleh modul DF player.

\section{KESIMPULAN DAN SARAN Kesimpulan}

Berdasarkan hasil penelitian yang dilakukan maka dapat disimpulkan bahwa alat penuntun bagi penyandang tunanetra sudah dapat berjalan sesuai fungsinya. ketika compass menunjukan kordinat $0 \circ$ kearah utara motor gear box akan menerima sensor pada kompas motor gear box akan bekerja sesuai seting jarak LCD sejauh $30 \mathrm{M}$, ketika heading $120^{\circ}$ ke arah timur gear box akan bekerja sesuai seting jarak lcd dan modul DF Player akan memberikan perintah serial microcontroller antara lain : LR (lurus), KR (kiri) dan Stop.

\section{Saran}

Dalam pembuatan alat penuntun bagi penyandang tunanetra, penulis menyadari masih 
terdapat kekurangan dan kelemahan pada alat tersebut diantaranya adalah sebagai berikut:

1. Pada alat ini tidak dapat mendeteksi bahwa di depan ada halangan.

2. Putaran pada motor gear box kurang masimal disebabkan alat penuntun tunanetra memiliki kapasitas beban $6 \mathrm{KG}$ sehingga torsi yang di hasilkan kurang maksimal.

3. Alat ini tidak dapat berfungsi melalui banyaknya unsur logam dan besi yang akan mengangu fungsi modul kompas.

\section{DAFTAR PUSTAKA}

Kurniawan, Hari. 2013." Aksebilitas Pada Gedung Baru Perpustakaan Universitas Gajah Mada", Tugas Akhir. Yogyakarta: Teknik Arsitektur dan Perencanaan, Universitas Gajah Mada.

Octa Risari, Rischa., Intan Kusumo, Diah. 2015."Pemanfaatan Jalur Pemandu Tunanetra Pada Pedestrian di Kota Semarang”, Jurnal Publikasi. Semarang: Universitas Diponegoro.

Syafi'ie, M. 2012.'Pemenuhan Aksebilitas Bagi Penyandang Disabilitas", Jurnal Publikasi. Yogyakarta: LSM Sigap Yogyakarta.

Sojadji s, 1989, Latihan-Latihan Dasar Orientasi Dan Mobilitas Bagi Anak Tunanetra Sebelum Usia Sekolah, Bandung, Remadja Karya.

Hidayat dan Suwandi. (2013). Pendidikan Anak Berkebutuhan Khusus Tunanetra. Jakarta Timur: PT. Luxima Metro Indah.

Pradopo, Soekani. (1977). Pendidikan Tunanetra, Bandung: N.V. MASA BARU.

Parkinson, B. W., Spilker, J.J. Jr., Global Positioning System: Theory and Applications, vols. 1 and 2, American Institute of Aeronautics, 370 L'Enfant Promenade, SW, Washington, DC, 1996.

El-Rabbany, Ahmed. (2002). Introduction to GPS : The Global Positioning System. (1stedtion). USA : Artech House.

Artanto.2012.APLIKASI KONTROLER ATMega 8535 dan ATMega16. Yogyakarta: ANDI.

Dwiono, Posma. 2014. "Alat Bantu Navigasi Penyandang Tuna Netra Mengunakan Sensor Ping dan Buzzer", Jurnal, Riau : Teknik Telekomonunikasi Politeknik Caltek.
Triarnowo, Susanto, Nugraha. 2013. "Pengembangan Sarung Tangan Sonar Sebagai Alternatif Alat Bantu Navigasi Bagi Tunanetra Mengunakan Arduino", Jurnal, Bandung : Fakultas Teknik Elektro Universitas Telkom.

Nurhamidah, Lubis, Taufik, 2015. “Alat Bantu Navigasi Tunanetra Otomatis Menggunakan Sensor Ultrasonic Berbasis Arduino Uno", Jurnal, Medan : Teknik Informatika, Sekolah Tinggi Harapan Medan. 